„Analecta Cracoviensia” 51 (2019), s. 141-16o

DOI: http://dx.doi.org/10.15633/acr.3637

ks. Lech Wołowski

ORCID: 0000-0003-2012-1267

Uniwersytet Papieski Jana Pawła II w Krakowie

\title{
Problem niezależności refleksji dramatycznej Józefa Tischnera od myśli teodramatycznej Hansa Ursa von Balthasara
}

\section{Wstęp}

W pierwszym tomie swojej Teodramatyki Hans Urs von Balthasar opisuje ciekawe zjawisko, które określa mianem „nieprzyczynowej równoczesności”, a które dotyczy jednoczesnego podjęcia niemal identycznej problematyki przez całkowicie niezależnych, choć współczesnych sobie, autorów. Balthasar wskazuje na wspomniane zjawisko, omawiając powstanie nowego nurtu teologiczno-filozoficznego opartego na tzw. zasadzie dialogicznej, będącego początkiem tego, co dziś zazwyczaj zwie się "filozofią dialogu” ${ }^{2}$.

Warto oddać tu na moment głos samemu autorowi:

H. U. von Balthasar, Teodramatyka, t. 1: Prolegomena, tłum. M. Mijalska, M. Rodkiewicz, W. Szymona, Kraków 2005, s. 595. Warto zwrócić uwagę na fakt, że Balthasar mówi tu z jednej strony o „nieprzyczynowej”, ale z drugiej strony o „nieprzypadkowej” równoczesności.

2 Balthasar z rozmysłem mówi o „zasadzie dialogicznej” lub też o „dialogizmie” (zob. H. U. von Balthasar, Teodramatyka, t. 1, dz. cyt., s. 596), unikając terminu „filozofia dialogu”. Dla szwajcarskiego teologa kluczowy jest bowiem fakt, iż cały nurt dialogiczny wywodzi się z tradycji biblijno-teologicznej, a dopiero później przejęty zostaje przez prąd filozoficzny: „Ogólnie nie ma wątpliwości, że pierwszy okres «dialogizmu» ma przeważnie charakter teologiczny" (H. U. von Balthasar, Teodramatyka, t. 1, dz. cyt., s. 596). 
To nie przypadek, że w roku śmierci Simmla, 1918, i w następnym, wydarzył się jeden $\mathrm{z}$ najbardziej osobliwych fenomenów „nieprzyczynowej równoczesności” w historii prądów duchowych i umysłowych: jednoczesne pojawienie się „zasady dialogicznej” na najbardziej oddzielnych polach. Jest ich czterech: trzej są odosobnieni: samotny nauczyciel szkoły podstawowej w Wiener Neustadt Ferdynand Ebner, we Frankfurcie Martin Buber, który do trzeciej i ostatniej części swojego Ja i ty dodaje wpływ Ebnera, ale do swoich centralnych założeń doszedł na podstawie o wiele wcześniejszych przemyśleń własnych; we Francji Gabriel Marcel, który prowadząc od 1914 r. swój Dziennik metafizyczny, właśnie około roku 1918 doszedł do niemal identycznych sformułowań. Wreszcie grupa skupiona wokół Franza Rosenzweiga, który jako uczeń Hermanna Cohena, ostatnie dzieło tegoż, Religion der Vernunft aus den Quellen des Judentums (1917-1918), czytał w postaci rękopisu. To w nim napisane było, że „dopiero Ty, odkrycie Ty, mnie samego prowadzi do świadomości mojego Ja”3.

Jest wielce prawdopodobne, że pisząc te słowa, Balthasar był zupełnie nieświadomy faktu, iż dokładnie w tym momencie, tzn. gdy rozpoczynał swą pracę nad Teodramatyka, nad pierwszym tomem, jego własnym udziałem stanie się niemal całkowicie analogiczny fenomen.

Tym razem chodzi o okoliczności powstania tzw. nurtu „refleksji dramatycznej", który to nurt, w pełnej analogi do nurtu dialogicznego, zaczyna w tamtych czasach rozwijać się zarówno w filozofii, jak i teologii.

Autorami, którzy niemal jednocześnie, choć w zupełnie odmiennych lokalizacjach i uwarunkowaniach geograficzno-polityczno-kulturowych, pracują nad teologią i filozofią dramatu, nie mając przy tym ze sobą bezpośredniego kontaktu, są Hans Urs von Balthasar i Józef Tischner. Warto pochylić się więc nad problemem, czy rzeczywiście także i tu mamy do czynienia ze wspomnianą wyżej „nieprzyczynową równoczesnością”, tj. czy podejścia „dramatyczne” Balthasara i Tischnera są od siebie niezależne.

Problemem tym zajmiemy się w niniejszym artykule.

H. U. von Balthasar, Teodramatyka, t. 1, dz. cyt., s. 595. Uwaga: zarówno tu, jak i w dalszej części artykułu, nie wchodzimy w kwestię wierności, adekwatności i jakości polskiego tłumaczenia niemieckojęzycznego tekstu Balthasara, choć w wielu przypadkach nie podzielamy decyzji tłumacza. Dyskusja tej kwestii nie mieściłaby się w ramach podjętego w tej pracy tematu. Przyjmujemy zasadę, że tam, gdzie jest dostępne polskie tłumaczenie, tam z niego korzystamy; w przeciwnym razie korzystamy $z$ oryginału niemieckojęzycznego. 
Zagadnienie to będzie wymagać zastosowania metody porównawczej w jej szczególnej odmianie. Nie wystarczy bowiem równolegle porównywać teksty obu autorów. Analizę należy rozbić na dwa odrębne etapy. Pierwszy z nich będzie polegał na ustaleniu niezależności myśli Balthasara od Tischnera. Tej analizie poświęcona zostanie pierwsza część głównego korpusu pracy (sekcja 2.1.). Następnie trzeba będzie zastanowić się nad niezależnością (lub ewentualną zależnością) refleksji Tischnerowskiej od Balthasarowskiej. Nietrudno się domyślić, iż analiza prowadzona w tym kierunku będzie dużo trudniejsza, wymagająca swego rodzaju ostrożności w formułowaniu tez i wniosków. Stąd druga część głównego korpusu pracy (sekcja 2.2.), poświęcona temu właśnie zagadnieniu, zostanie zdecydowanie bardziej rozbudowana i podzielona na kilka podsekcji.

Całość zamkniemy podsumowaniem, w którym w syntetyczny sposób postaramy się przedstawić wnioski z uzyskanych wyników badań.

\section{Analiza niezależności myśli dramatycznej obu autorów}

Problem analizy niezależności myśli współczesnych sobie autorów, pracujących nad zbliżoną tematyką - nawet jeśli zawężony zostanie do pewnego specyficznego zakresu tematycznego ${ }^{4}$ - rzadko bywa problemem trywialnym. Wymaga, mimo wszystko, ogarnięcia całokształtu dzieła obu twórców, jak również zwrócenia uwagi na pewne istotne szczegóły, które mogą zadecydować o istnieniu lub braku wzajemnego lub przynajmniej jednostronnego wpływu. Należy przy tym pamiętać, że poziom trudności nie jest tu zazwyczaj symetryczny. Najczęściej łatwiej jest wykazać wspomnianą niezależność w jednym kierunku, a już dużo trudniej w drugim. Jak już wspomnieliśmy, nie inaczej jest w naszym przypadku.

Mimo iż okresy życia Balthasara (1905-1988) i Tischnera (1931-200o) w dużej mierze się zazębiły, już z samego dość znacznego przesunięcia w czasie widać, że młodszy z nich miał dużo mniejszą szansę na wpłynięcie na twórczość starszego. Oprócz tego, oczywistego, czynnika dochodzą także inne, takie jak np. sława: autor mniej sławny ma mniejszą siłę i zakres oddziaływania.

\footnotetext{
4 W naszym przypadku jest to rys „dramatyczny” myśli obu autorów. Nie oznacza to jednak, iż wnioski dotyczące niezależności ich myśli ograniczają się wyłącznie do tego zakresu. Jest wręcz przeciwnie. Ograniczamy się do pola „dramatycznego” dlatego, że jest to największe pole przecięcia się wspólnych zainteresowań obu autorów. Trudno byłoby bowiem doszukiwać się zależności pomiędzy nimi na obszarach tematycznie rozłącznych.
} 
Niebagatelną rolę odgrywają również uwarunkowania polityczno-geograficzne, które niejednokrotnie mogą zdecydowanie ułatwić, lub też odwrotnie, całkowicie niemal uniemożliwić komunikację.

Nasze studium rozpoczniemy od wykazania niezależności refleksji teodramatycznej Balthasara od myśli dramatycznej Tischnera.

\subsection{Niezależność Balthasara od Tischnera}

Niezależność myśli, nie tylko teodramatycznej, ale w ogólności teologicznej i filozoficznej Balthasara od Tischnera nie ulega praktycznie żadnej wątpliwości. Niemniej jednak musimy przedstawić konkretne argumenty, które upewnią nas co do takiego stanu rzeczy.

Pierwszy argument, wcześniej już zarysowany, jest oczywisty: różnica wieku. Biorąc pod uwagę fakt, że Balthasar był 26 lat starszy od Tischnera oraz to, iż zaczął on publikować w stosukowo młodym wieku, łatwo ustalić, że pierwsze publikacje szwajcarskiego teologa zdążyły się pojawić, gdy Tischnera nie było jeszcze na świecie ${ }^{5}$. Ta sytuacja czasowego dystansu eliminującego jakąkolwiek możliwość zależności Balthasara od Tischnera trwać będzie jeszcze przez niemal kolejne ćwierćwiecze, czyli do momentu święceń kapłańskich Polaka (1955) i niedługo potem pojawienia się pierwszych jego prac naukowych $^{6}$. Balthasar jest wówczas ponad pięćdziesięcioletnim, dobrze znanym już na całym świecie i - co najważniejsze - w pełni ukształtowanym teologicznie i filozoficznie myślicielem. Słynie on ponadto z niezwykle stabilnej i konsekwentnej myśli, która wprawdzie, jak w każdym twórczym przypadku, ewoluowała i rozwijała się, niemniej jednak, nie przechodziła nigdy

5 Pierwszym artykułem opublikowanym przez Balthasara jest praca Die Entwicklung der musikalischen Idee pochodząca z 1925 roku. Nie można jednak zaliczyć jej do dzieł teologicznych. Pierwszą pracą, również jeszcze nie ściśle teologiczną, ale posiadającą wyraźne aspekty teologiczne, jest rozprawa doktorska Balthasara Geschichte des eschatologischen Problems in der modernen deutschen Literatur, opublikowana w 1930 roku (zob. Hans Urs von Balthasar. Bibliographie 1925-2005. Neu bearbeitet und ergänzt von Cornelia Capol und Claudia Müller, Einsiedeln-Freiburg 2005).

Podobnie jak Balthasar, również Tischner bardzo wcześnie rozpoczyna swoją przygodę z szeroko pojętym piśmiennictwem (już w 1944 roku zaczyna pisać swój dziennik - zob. J. Tischner, Dziennik 1944-1949. Niewielkie pomieszanie klepek, Kraków 2014, passim). Za pierwszą pracę naukową Tischnera przyjmuje się zazwyczaj jego krótką recenzję Epistemologii Fernanda Van Steenberghena, opublikowaną w 1955 roku w „Collectanea Theologica”. Natomiast w pełni samodzielne i twórcze prace naukowe Tischnera przypadają na początek lat sześćdziesiątych (w roku 1963 broni pracę doktorską pt. Ja transcendentalne w filozofii Edmunda Husserla - zob. J. Tischner, Studia z filozofii świadomości, Kraków 2006, s. 9-127). 
przez radykalne zwroty czy spektakularne metamorfozy. Nawet jego myśl teodramatyczna, nowatorska i jakże oryginalna, wypływa w naturalny sposób z całokształtu wcześniejszego wykształcenia i konsekwentnego późniejszego rozwoju oryginalnych idei tego autora ${ }^{7}$.

Tam gdzie Balthasar sięga do źródeł lub opracowań, zawsze w obfitości pojawiają się nazwiska autorów, z których korzysta ${ }^{8}$. Nie bez racji Herni de Lubac nazwał go największym erudytą xx wieku' ${ }^{9}$ Na próżno byłoby jednak szukać Tischnera wśród wymienianych przez Balthasara nazwisk. Nie powinno to jednak dziwić. Na początku lat siedemdziesiątych, kiedy to Balthasar rozpoczynał pracę nad Teodramatyka, Tischner całkowicie pochłonięty był problematyką, jaką opracowywał w ramach swej pracy habilitacyjnej, tj. niemal czysto filozoficznymi zagadnieniami fenomenologicznymi dotyczącymi świadomości egotycznej ${ }^{10}$. Nie był to jeszcze czas ani szczytowej działalności naukowej polskiego myśliciela, ani też okres jego zainteresowań tematyką dialogiczno-dramatyczną.

Czas ten nadejdzie dużo później, w drugiej połowie lat osiemdziesiątych, kiedy to można mówić o początku drugiej fazy myśli filozoficznej Tischnera, który z czasem, zwłaszcza w dekadzie lat dziewięćdziesiątych, niemal bez reszty poświęci się problematyce filozofii dialogu i dramatu i coraz częściej sięgać będzie po inspirację, literaturę i tematykę nie tylko filozoficzną, ale i teologiczną. Wszystko to dzieje się jednak nie tylko po opublikowaniu Teodramatyki przez Balthasara, ale już wręcz po jego śmierci. To, co Tischner powiedział i napisał po roku 1988, nie mogło mieć już żadnego wpływu na twórczość, kończącego w tymże roku swój żywot, Balthasara.

Dystans czasowy, jaki oddzielał Balthasara od Tischnera został dodatkowo spotęgowany dystansem geograficzno-politycznym, przy czym ten drugi, tj. polityczny miał zdecydowanie większe znaczenie. Wszechobecna cenzura wewnętrzna i skuteczne uniemożliwianie publikacji prac filozoficzno-teologicznych (niezgodnych z oficjalną marksistowską propagandą komunistyczną) polskich autorów w periodykach zagranicznych niemal całkowicie odcięły nie

7 Konsekwentny i systematyczny rozwój myśli Balthasara, zwieńczony „sumą” w postaci Trylogii, przedstawiony jest w pracy E. Guerriero, Hans Urs von Balthasar. Monografia, Kraków 2004, passim.

8 Dobitnie świadczą o tym obfite indeksy autorów cytowanych w poszczególnych tomach Teodramatyki.

9 Por. E. Guerriero, Hans Urs von Balthasar. Monografia, dz. cyt., s. 24.

${ }^{10}$ Zob. J. Tischner, Fenomenologia świadomości egotycznej, w: J. Tischner, Studia z filozofi świadomości, dz. cyt., passim. 
tylko Balthasara, ale większość ówczesnych myślicieli zachodnich od filozoficzno-teologicznej (i tak przecież mocno okrojonej i uciśnionej) myśli niezależnych twórców żyjących w bloku tzw. państw komunistycznych. „Żelazna kurtyna" wprawdzie w końcu opadła, ale stało się to już niestety po śmierci Balthasara ${ }^{11}$.

Wszystkie wspomniane wyżej okoliczności skłaniają nas do konkluzji, iż Balthasar nie tylko nie miał fizycznej możliwości dotarcia do poświęconych omawianej przez nas tematyce prac Tischnera, ale wręcz prawdopodobnie nie był świadomy ich istnienia ${ }^{12}$.

Brak jakiegokolwiek, nawet pośredniego czy drugorzędnego, odwołania do Tischnera u Balthasara (nie tylko w Teodramatyce) nie może więc nikogo dziwić i pozostaje najwymowniejszą ilustracją tezy o całkowitej niezależności jego twórczości od twórczości krakowskiego myśliciela.

\subsection{Niezależność Tischnera od Balthasara}

O ile kwestia niezależności Balthasara od Tischnera była niemal oczywista, o tyle problematyka niezależności w drugą stronę jest już zagadnieniem dużo bardziej skomplikowanym, niejednoznacznym i co najmniej dwupoziomowym. Trzeba będzie bowiem rozróżnić pomiędzy dwoma poziomami wpływu: czysto formalnym i rzeczywistym. Nim jednak dojdziemy do subtelniejszych rozróżnień, musimy na początku ustalić pewne fakty podstawowe.

Na pierwszy rzut oka dość dużo argumentów zdaje się przemawiać za zależnością Tischnera od Balthasara. Już pierwszy argument, wykorzystany w poprzedniej analizie, tj. przesunięcie czasowe, który przemawiał zdecydowanie na korzyść Balthasara, teraz będzie musiał przemawiać na niekorzyść Tischnera. Skoro ustaliliśmy, że w chwili, kiedy Polak rozpoczyna swą działalność naukową, Szwajcar jest już znanym (choć trzeba wyraźnie dodać,

${ }^{11}$ Balthasar umiera 26 czerwca 1988 roku, na niecały rok przed oficjalnym rozpoczęciem demokratycznych przemian w Polsce i w całej Europie Środkowo-Wschodniej.

${ }^{12}$ Inną kwiestą, którą pominiemy w obecnych rozważaniach, jest zaskakująco znikoma liczba odniesień Balthasara do jakiegokolwiek polskiego autora, czy choćby w ogólności do polskiej literatury, niekoniecznie teologicznej (przy równoczesnych, częstych odniesieniach np. do literatury rosyjskiej). Dość powiedzieć, że w całej czterotomowej Teodramatyce (poza lakoniczną wzmianką o ojcu M. Kolbe - por. H. U. von Balthasar, Teodramatyka, t. 2, cz. 2, tłum. W. Szymona, Kraków 2006, s. 427) można się doszukać praktycznie jednej tylko wzmianki dotyczącej Polski (oczywiście nie wchodzą tu w rachubę odniesienia do Ericha Przywary), i to w skrajnie marginalnym kontekście, jakim jest wygnanie z Polski zwolenników Socyna Sieneńskiego (por. H. U. von Balthasar, Teodramatik, Bd. 3, s. 248). 
że nie przez wszystkich jednakowo szanowanym i docenianym, a w niektórych przypadkach wręcz izolowanym i pomijanym ${ }^{13}$ ) teologiem, to informacja o tym, że ktoś taki jak Balthasar istnieje, musiała wcześniej czy później do Tischnera dotrzeć. Tischner oczywiście nie musiał interesować się Balthasarem w pierwszej fazie swojej naukowej kariery, kiedy to zgłębiał tajniki bardzo specjalistycznego działu filozofii świadomości. Twórczość Balthasara, niezależnie od jej rozległości, nie mogła należeć wówczas do źródeł myśli Tischnerowskiej.

Należy tu jeszcze raz przypomnieć o wszechobecnej w tamtych czasach „żelaznej, kurtynie”, która - w przeciwieństwie do argumentu z przesunięcia czasowego - bardzo skutecznie działała w obie strony, tj. nie tylko uniemożliwiła Balthasarowi dowiedzenie się czegoś o Tischnerze, ale przede wszystkim zdecydowanie utrudniła i opóźniła zetknięcie się Tischnera z pracami Balthasara, a także z pracami jego współpracowników i uczniów ${ }^{14}$.

„Żelazna kurtyna” jednak opadła, i to dokładnie w czasie, kiedy Tischner wchodził w okres największego zainteresowania problematyką dialogu i dramatu. Siłą rzeczy musiał więc zetknąć się w pewnym momencie z myślą Balthasara.

Postaramy się odnaleźć te miejsca, w których Tischner bezpośrednio cytuje lub odnosi się do prac szwajcarskiego uczonego. Interesować nas będzie również terminologia - czy pokrywa się ona $\mathrm{z}$ terminologią Balthasara, czy jest choćby zapożyczona od niego, czy też jest wręcz przeciwnie. Sam bowiem fakt nawiązywania do innego autora czy cytowania go, nie przesądza jeszcze o zależności od niego. Trzeba będzie dokonać wspomnianej już wyżej analizy dwupoziomowej, tj. odróżnić momenty formalnego („grzecznościowego”)

${ }^{13}$ Por. np. E. Guerriero, Hans Urs von Balthasar. Monografia, dz. cyt., s. 13. O izolacji Balthasara (w pewnych kręgach) dobitnie świadczy chociażby fakt niezaproszenia go, jako eksperta, na sobór watykański II. Z czasem, zwłaszcza za pontyfikatu św. Jana Pawła II, izolacja ta została przełamana i zniwelowana, czego najlepszym wyrazem była (ogłoszona pod koniec jego życia) nominacja kardynalska.

${ }^{14} \mathrm{~W}$ tym momencie musimy poczynić pewne zastrzeżenie metodologiczne. Biorąc pod uwagę potężny zasięg myśli Balthasara na Zachodzie, liczbę jego publikacji, niemały krąg jego współpracowników, a później stopniowo także i uczniów, nie sposób w tym krótkim artykule pokusić się o próbę analizy pośredniego wpływu Balthasara na Tischnera. Jest bowiem oczywiste, że zwłaszcza w latach osiemdziesiątych i dziewięćdziesiątych liczba prac i autorów, którzy w jakimś stopniu pozostają zależni od Balthasara, jest tak ogromna, że Tischner, szczególnie wchodząc w fazę swoich zainteresowań filozofią dialogu i dramatu, musiał się zetknąć z pracami nawiązującymi do Balthasara. Dotyczy to jednak w takim samym stopniu Balthasara, co i pozostałych „wielkich” przedstawicieli teologii xx wieku. Tego typu wpływu nie będziemy tu analizować. 
cytowania od momentów istotnego wykorzystania myśli drugiego autora. Ważna będzie tu zwłaszcza datacja. Nie ulega bowiem wątpliwości, że Tischner cytuje Balthasara, i to nawet w jednym z najważniejszych swoich dzieł dotyczących problematyki „dramatu człowieka”, jakim jest Spór o istnienie człowieka. Trzeba jednak ustalić czasokres i charakter tego odniesienia, zanim spróbuje się „zawyrokować” o ewentualnym rzeczywistym wpływie. Można znaleźć również inne, poboczne, drugorzędne, czy wręcz epizodyczne nawiązania Tischnera do Balthasara. O nich również wspomnimy, gdyż zdecydowanie wzbogacą one naszą analizę.

\subsubsection{Analiza przypadków bezpośrednich odniesień Tischnera do Balthasara}

a) Wywiad z Tischnerem z 1999 roku

Zaczynamy od odniesienia pozornie drugorzędnego, czy wręcz, zdawać by się mogło, marginalnego, które pojawiło się niemalże mimochodem w jednym z wywiadów, jaki Tischner udzielił Dorocie Zańko i Jarosławowi Gowinowi niemal pod koniec swojego życia ${ }^{15}$.

W trakcie tej rozmowy - poruszając temat ofiary, nadziei i odkupienia Tischner wprowadza pojęcie „teologii wdzięczności”, której rdzeniem staje się „chwała na wysokości Bogu”, a której jednym z najwybitniejszych, zdaniem Tischnera, przedstawicieli jest, nie kto inny, jak sam Balthasar:

Nikt współcześnie nie wyraził tego podziwu dla Boga wspanialej niż Hans Urs von Balthasar. Miałbym ochotę powiedzieć, że kto go nie czytał, nie wie naprawdę, czym jest horyzont wiary. Wiara Balthasara jest inna niż wiara ojca Kolbego. Ale gdyby ktoś dał mi do wyboru jedną lub drugą wiarę, to nic nie ujmując Kolbemu, wybrałbym Balthasara ${ }^{16}$.

Choć odniesienie to nie jest wyrażone explicité, z kontekstu można się domyślić, iż Tischner nawiązuje tu do pierwszej części Trylogii Balthasara, czyli właśnie do Chwały. Na pierwszy rzut oka nawiązanie to nie ma więc praktycznie nic wspólnego z myślą dramatyczną żadnego z nich. Sytuacja klaruje się jednak po następującym, doprecyzowującym, pytaniu interlokutora: „Ma

${ }^{15}$ Przekonać Pana Boga..., dz. cyt., passim.

${ }^{16}$ Przekonać Pana Boga..., dz. cyt., s. 26. Nie wchodzimy tu w kwestię adekwatności lub w ogóle stosowności użytego przez Tischnera porównania pomiędzy Balthasarem i o. Kolbem. Nie jest bowiem przedmiotem naszych rozważań treść tego porównania, lecz fakt, że Tischner odwołuje się w nim do Balthasara. 
Ksiądz Profesor pewność, że ktoś wierzący jak Balthasar zrobiłby w Oświęcimiu to co Kolbe?" ${ }^{\prime 7}$.

Pytanie to zmusiło Tischnera do podzielenia się ze słuchaczami bardzo głęboką myślą dotyczącą nie tylko dramatyczności zarysowanej tu sytuacji, lecz czegoś więcej, dramatyczności teologii jako takiej, a nawet dramatyczności samych badań teologicznych:

Myślę inaczej - że Balthasar w drodze do swojej wiary w pewnym sensie zrobił to co Kolbe. Ryzyko, jakie podejmuje wielki teolog, mówiąc o Bogu, jest większe niż ryzyko oddania życia za drugiego. Mistrz Eckhart, wytyczający drogi rozwoju człowieczeństwa, myślenia o Bogu i o bliźnim, wysuwał niesamowicie śmiałe twierdzenia, od których aż ciarki przechodzą po grzbiecie. Podobnie Dionizy Pseudo-Areopagita czy Grzegorz z Nyssy. W ich dziełach dokonywały się epokowe rozstrzygnięcia! Promieniuje z nich nadludzki heroizm! ${ }^{18}$

Z tych dwóch krótkich wypowiedzi można od razu wyciągnąć kilka zasadniczych wniosków. Po pierwsze, widać jasno, że Tischner darzył Balthasara nie tylko wielkim szacunkiem, lecz wręcz podziwem i estymą. Nie przez przypadek stawia jego nazwisko na równi z „wielkimi”; tak go zresztą nawet sam nazywa.

Po drugie, krakowski myśliciel zauważa tu pewną prawidłowość: by być prawdziwym filozofem lub teologiem dramatu, nie można uprawiać tej dziedziny w czysto abstrakcyjny sposób, zajmując się dramatem „na sucho”. Trzeba samemu ten dramat przeżyć - już samo podjęcie tematyki dramatycznej jest przedsięwzięciem dramatycznym. Tischner wyraźnie zaznacza, iż tak właśnie było w przypadku Balthasara. W następnej podsekcji będziemy mieli okazję przekonać się, że prawidłowość ta stała się udziałem także jego samego.

Po trzecie, i to jest najważniejsze dla nas ustalenie, nie ulega wątpliwości, że Tischner musiał czytać Balthasara, a nie tylko o nim słyszeć. Inaczej nie pozwoliłby sobie na stwierdzenie, że „kto go nie czytał, nie wie naprawdę, czym jest horyzont wiary".

Cytat ten ma więc istotne, a nie marginalne, znaczenie dla naszych rozważań. Gdyby słowa te wypowiadał młody Tischner, już z tych ustaleń należałoby wyciągnąć wniosek, że jego twórczość nie tylko musiałaby być uzależniona od Balthasara, ale wręcz, że pozostawałaby pod jego ogromnym wpływem.

${ }^{17}$ Przekonać Pana Boga..., dz. cyt., s. 26.

${ }_{18}$ Przekonać Pana Boga..., dz. cyt., s. 26. 
Nie byłoby bowiem możliwe, żeby młody autor tak bardzo ceniący drugiego nie skorzystał w swej dalszej twórczości z jego dzieł.

Słowa te padają jednak nie z ust młodego, ale niemal już umierającego Tischnera. Zamiast zapowiadać program jego przyszłej twórczości, wyrażają raczej żal, że tak późno miał on okazję zapoznać się z tak wielkim i cennym autorem. b) Artykuł z 1998 roku o życiu wewnętrznym Boga

Innym miejscem, gdzie znajdujemy już bardziej systematyczne odniesienia Tischnera do Balthasara jest artykuł poruszający problematykę wolności i dialogicznych relacji intratrynitarnych zatytułowany Życie wewnętrzne Boga ${ }^{19}$.

Artykuł ten Tischner pisze na dwa lata przed swoją śmiercią, nie tylko poruszając w nim problematykę dramatu wolności Boga i człowieka, ale przeżywając samemu dramat okoliczności, w jakich przyszło mu te słowa pisać: „Okoliczności zewnętrzne sprawiły, iż praca ta powstawała w szpitalu. Kiedy walczono o moje życie, ja walczyłem z myślami, które mnie nawiedzały «na manowcu»" ${ }^{20}$. Nie tylko jednak okoliczności powstania wyróżniają ten tekst Tischnera spośród wielu innych. Już sam tytuł i tematyka wydają się być nietypowe dla tego autora. Oczywiście myśliciel, zwłaszcza w końcowej fazie swej twórczości naukowej, nie stronił od problematyki teologicznej, niemniej jednak rzadko kto spodziewałby się po nim artykułu, w którym rozważa się niuanse relacji intratrynitarnych. Nic więc dziwnego, że już na samym początku dzieli się on z czytelnikiem informacją, iż nie wyrusza w tę trynitarną podróż samodzielnie. Inspiracją do napisania tej pracy była lektura kluczowych dla rozwoju teologii współczesnej specjalistycznych prac trynitologicznych, których autorzy stają się dla niego przewodnikami w tej dziedzinie:

Moimi przewodnikami po złożonej problematyce i ogromnej literaturze są: Gisbert Greshake oraz Hans Urs von Balthasar. Ten pierwszy opublikował niedawno pokaźne dzieło poświęcone teologii trynitarnej, drugi jest autorem wielotomowych prac, w których problem Trójcy powraca kilkakrotnie. Do tego dochodzi również niebagatelne studium habilitacyjne Martina Bielera, poświęcone „wolności i łasce”, w którym szuka on między innymi śladów „dialogiczności” $\mathrm{w}$ „monologicznej” konstrukcji myśli św. Tomasza ${ }^{21}$.

19 J. Tischner, Życie wewnętrzne Boga, w: J. Tischner, Ksiądz na manowcach, Kraków 2007, s. $88-101$.

${ }_{20}$ J. Tischner, Ksiadz na manowcach, dz. cyt., s. 6.

${ }^{21}$ J. Tischner, Ksiądz na manowcach, dz. cyt., s. 92. 
Mamy tu więc znowu bezpośrednie odniesienie do Balthasara, do którego w tym artykule Tischner odwoływać się będzie bardzo często. W przeciwieństwie jednak do poprzednio omówionej epizodycznej wzmianki, teraz Balthasar może być już znany za źródło podstawowe. Zależność Tischnera od Balthasara jest tak silna w tym artykule, że nawet gdyby nie był on ani razu zacytowany $\mathrm{z}$ imienia i nazwiska, to już po samej terminologii można by wnioskować o silnej zależności od myśli szwajcarskiego teologa. Wyrażenia takie jak, „wolność skończona” i „wolność nieskończona”, typowe dla Balthasara, a niespotykane dotąd u Tischnera, są tego najdobitniejszym przykładem ${ }^{22}$.

Należy jednak zauważyć, że korzystając tak obficie z Balthasara w tej konkretnej pracy, Tischner nie ukrywa w żaden sposób swego źródła. Mało tego, jak na stosunkowo krótki artykuł, a przecież nieoparty wyłącznie na Balthasarze, siedmiokrotne imienne do niego odwołanie zdaje się być aż nadmiarowe.

Z obserwacji tej płynie bardzo ważny wniosek: kiedy Tischner opiera swą myśl na pracach innych autorów, tu w szczególności na Balthasarze, nie tylko daje się od razu wyczuć ten wpływ w sposobie opisu i terminologii, jakiej używa, ale przede wszystkim dostrzega się, że sam Tischner dba o to, by wyraźnie odnotować źródła, z których korzysta, poprzez odpowiednie cytowania i odnośniki.

\section{c) Ostatni rozdział Sporu o istnienie człowieka z 1998 roku}

Najważniejszy tekst Tischnera zawierający bezpośrednie odnośniki do Balthasara to ostatni rozdział ostatniego jego wielkiego dzieła, tj. Sporu o istnienie człowieka, uważanego przez samego autora z drugą część jego Filozofii dra$m a t u^{23}$, a więc dzieła na wskroś przeszytego myślą dramatyczną tego autora i można powiedzieć zawierającego jej syntezę. Rozdział, o którym mowa, otrzymał bardzo charakterystyczny tytuł: Boski rodowód wolności, czyli: „bądź wolność Twoja"na . Już w samym wstępie do tego rozdziału Tischner dzieli się z czytelnikiem źródłami, na których oprze swoją myśl:

${ }^{22}$ Jako przykład użycia tych terminów wystarczy zacytować zdanie: „Chrystus jako człowiek poddaje swą skończoną wolność nieskończonej wolności Boga” (J. Tischner, Ksiądz na manowcach, dz. cyt., s. 89).

${ }^{23}$ Por. J. Tischner, Spór o istnienie człowieka, Kraków 2011, s. 5.

24 J. Tischner, Spór o istnienie człowieka, dz. cyt., s. 374-411. Ten sam tekst ukazał się również w czerwcowym wydaniu „Znaku” z 1998 roku pod tym samym tytułem. Należy zwrócić uwagę na błąd, jaki wkradł się w datacji tego artykułu w Bibliografii prac drukowanych księdza Józefa Tischnera autorstwa Stanisława Ludwika Piecha: zamiast prawidłowego cytowania: „Znak” 50: 1998 nr 6 (517) s. 101-118, podano błędne: „Znak” 49: 1997 nr 6 (517) s. 101-118. Różnorodne komentarze 
Mam przed sobą trzy ważne prace współczesnej teologii. Najpierw jest to Gisbert Greshake i jego trynitarna teologia, o trudnym do dokładnego spolszczenia tytule: Der dreieine Gott (1997). Obok niej leży Martina Bielera Freiheit als Gabe (Wolność jako dar, 1991). I wreszcie kilkanaście tomów Hansa Ursa von Balthasara zatytułowanych Theologik i Theodramatik - opus magnum jednego z najwybitniejszych teologów naszych czasów ${ }^{25}$.

Czytając te słowa, ma się nieodparte wrażenie świeżości, dosłownie jakby książki te dopiero co „wylądowały” na biurku Tischnera, a ten pochłaniał je z zapartym tchem, chcąc zdążyć jeszcze nawiązać do nich przynajmniej w tym ostatnim rozdziale swej pracy. Warto tu nadmienić, że - jak pisze

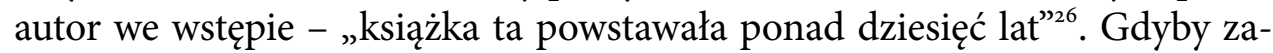
tem wspomniane źródła były wcześniej Tischnerowi znane, to z całą pewnością zechciałby nawiązać do nich już we wstępie do całego dzieła. Z nie mniejszą pewnością można stwierdzić, iż niejednokrotnie nawiązałby do nich we wcześniejszych rozdziałach, a nie czekał aż do ostatniego. Najwyraźniej widać to w interesującej nas kwestii odnośników do Balthasara: podczas gdy w ostatnim rozdziale Sporu o istnienie człowieka aż roi się od cytatów i odnośników do Teodramatyki, w żadnym poprzednim rozdziale nie ma o tym autorze i jego dziele nawet wzmianki.

Można więc wnioskować, że niemal całość Sporu o istnienie człowieka Tischner napisał zanim zetknął się ze wspomnianymi wyżej dziełami Balthasara, a moment, w którym do tego zetknięcia doszło, musiał niemal bezpośrednio poprzedzać czas, kiedy kończył już swe wieloletnie dzieło, pisząc jego

do tego tekstu Tischnera znajdzie czytelnik w: J. Jagiełło, W. Zuziak, Bądź wolność twoja, Kraków 2005, passim. Por. także A. Bobko, Myślenie wobec zła, Kraków-Rzeszów 2007, s. 318-326.

${ }_{25}$ J. Tischner, Spór o istnienie człowieka, dz. cyt., s. 379. Zauważmy, że Tischner mówi tu o „kilkunastu” tomach. Można więc wnioskować, że ma na myśli również pierwszą część trylogii, Herrlichkeit, choć nie wsponina o niej jawnie, być może dlatego, iż w tym konkretnym tekście nie zamierza do tej części się odwoływać.

${ }^{26}$ Jest to dosłownie pierwsze zdanie ze wstępu do tej pracy (zob. J. Tischner, Spór o istnienie człowieka, dz. cyt., s. 5). Warto jednak dodać, że „ponad dziesięć lat” to i tak dość „skąpe oszacowanie”. Przypomnijmy, że już w 1977 roku w swym artykule pt. Przestrzeń obcowania $z$ drugim („Analecta Cracoviensia” 9 (1977), s. 67-86), Tischner w przypisie do tytułu tego artykułu podaje następujący komentarz: „Fragment większej całości przygotowywanej do druku, pt. Spór o istnienie człowieka”. I mimo że treść tego artykułu bezpośrednio nie znalazła się w wydaniu książkowym Sporu, to jednak na podstawie tego komentarza przyjąć można, iż książka, o której tu mowa, powstawała tak naprawdę ponad dwadzieścia lat. 
ostatni rozdział. Należy bowiem podkreślić wyraźnie, że Tischner nigdy nie miał problemu z należytym przywoływaniem podstawowych źródeł swojej myśli, także dramatycznej. Najlepszym przykładem jest tu Lévinas, z którego filozofią spotkał się już na bardzo wczesnym etapie swej kariery naukowej ${ }^{27}$ i później nigdy nie stronił od dokumentowania zależności swojej myśli dramatyczno-dialogicznej od jego prac.

Co ciekawe, doszło wręcz do tego, że Tischner, zapoznając się z dziełami Balthasara, w szczególności z jego podstawową ideą relacji wolności skończonej i nieskończonej, ze zdumieniem stwierdza u niego brak jakiegokolwiek odniesienia właśnie do Lévinasa. Uwagą taką dzieli się z czytelnikami w rozważanym przez nas tekście w kontekście dwóch sformułowań użytych przez Balthasara: „moment nieskończoności” i „tęsknota”, które zdaniem Tischnera, obowiązkowo niemalże powinny przywołać na myśl Lévinasowską koncepcję "pragnienia”:

Obecny we wnętrzu wolności skończonej moment Nieskończoności - pisze Balthasar - „nazywamy obojętnością wobec wszelkich dóbr skończonych lub absolutną tęsknotą za tym, co niedoścignione.... Mamy zatem: obojętność i tęsknotę, tęsknotę i obojętność. Trudno powiedzieć, co jest pierwsze. Obojętność pobudza tęsknotę, tęsknota pobudza obojętność. Szkoda, że u Balthasara nie ma w tym miejscu śladów wspływu myśli Lévinasa. Aż się prosi, by przypomnieć Lévinasową koncepcję „pragnienia”, właśnie jako „absolutnej tęsknoty”28.

Warto zaznaczyć, na marginesie, że mamy tu do czynienia z bardzo ciekawym zjawiskiem. Mianowicie, dla współczesnego teologa zachodniego jest rzeczą nie do pomyślenia rozwijanie jakiejkolwiek myśli dramatycznej, a już zwłaszcza takiej, która zahacza o problematykę teologiczną, bez odniesienia się do Balthasara. Niemniej jednak, jak ustalimy to w następnej sekcji, Tischnerowi, chcąc nie chcąc, niemalże udała się ta sztuka, z małymi wyjątkami, właśnie tymi, które rozważamy w obecnej sekcji. Z drugiej zaś strony dla Tischnera byłoby nie do pomyślenia rozwijanie myśli dramatycznej bez jakiegokolwiek odwołania się do Lévinasa. Tymczasem w całej swej Teodramatyce Balthasar nie odwołuje się do Lévinasa ani razu, mimo że w tym wypadku nie można tego uzasadnić nieznajomością dzieł francuskiego filozofa.

27 Tischner cytuje Lévinasa już w swoim doktoracie z 1963 roku.

28 J. Tischner, Spór o istnienie człowieka, dz. cyt., s. 385. Por. H. U. von Balthasar, Teodramatyka, t. 2: Osoby dramatu, cz. 1: Człowiek w Bogu, tłum. W. Szymona, Kraków 2006, s. 188. 
Obserwacja ta jest o tyle istotna $\mathrm{z}$ naszego punktu widzenia, iż zarysowuje się dzięki niej dość wyraźna linia oddzielająca źródła myśli Balthasara i Tischnera. Podczas gdy Balthasar wręcz z premedytacją odcina się od Lévinasa, Tischner - przedstawiając podstawowe paradygmaty swej myśli dramatycznej w pierwszej części swojej Filozofii dramatu - deklaruje, częściową wprawdzie, ale wyraźną, a miejscami nawet fundamentalną, zależność od tego autora ${ }^{29}$.

Ponownie więc spotykamy się tu z sytuacją, w której jasno widać, że jeśli Tischner zawdzięcza w swojej myśli dramatycznej wątki lub aspekty pochodzące od innego autora, to nie tylko wyraźnie sam to zaznacza, ale nawet wskazuje, do jakiego stopnia zależność ta jest posunięta.

\subsubsection{Próba rozstrzygnięcia kwestii niezależności Tischnera od Balthasara}

$\mathrm{Z}$ tego, co zdołaliśmy ustalić w poprzedniej sekcji, wynika, że nie da się postawić generalnej tezy o całkowitej niezależności myśli dramatycznej Tischnera od Balthasara. Ważne jest jednak, by ze zgromadzonego materiału nie wyciągać zbyt pochopnych lub zbyt daleko idących wniosków. Najważniejszą bowiem kwestią, pozostającą do rozstrzygnięcia, jest pytanie, czy zależność ta jest istotna czy jedynie marginalna.

Nie przez przypadek już w samych nagłówkach podsekcji, zaznaczaliśmy w poprzedniej sekcji lata, w których powstawały dzieła zawierające jakiekolwiek nawiązania do Balthasara. Mamy tu do czynienia z pracami jedynie z okresu ostatnich dwóch lat życia Tischnera (1998-2000). Biorąc pod uwagę jego aktywność naukową, rozciągającą się w okresie niemal półwiecza, nie sposób uznać ostatnich dwóch lat za dominujące. Jest ponadto oczywiste, że owe ostatnie lata nie mogły wpłynąć na wcześniejszą twórczość. Bez żadnej przesady można powiedzieć, że w 1998 roku myśl dramatyczna Tischnera była już w pełni dojrzała i ukształtowana.

Trzeba jednak pamiętać, że sam fakt ograniczenia bezpośrednich odniesień do Balthasara do dwóch ostatnich lat życia Tischnera nie stanowi jeszcze

${ }^{29}$ Już w pierwszym rozdziale Filozofii dramatu Tischner pisze: „Podejmując rysujący się tu problem, pragnę nawiązać do poglądów Emmanuela Lévinasa” (J. Tischner, Filozofia dramatu, Kraków 2012, s. 25). Kolejne podpunkty tego rozdziału, dotyczące problematyki „twarzy”, „innego”, „pragnienia”, „śladu” i wreszcie dobra, są jak gdyby prezentacją kluczowych idei zawartych w myśli Lévinasa. Prezentację tę Tischner kończy słowami: „Dokonane przedstawienie poglądów Lévinasa miało charakter wybiórczy. Ukazało jedynie te fragmenty, które były szczególnie bliskie autorowi tych rozważań" (J. Tischner, Filozofia dramatu, dz. cyt., s. 61). Mamy tu więc pozostawiony nam przez Tischnera podręcznikowy niemal przykład, jak należy dokumentować wpływ innych autorów na własną myśl. 
dowodu, iż nie mógł on wcześniej zaznajomić się z dziełami szwajcarskiego teologa, następnie niepostrzeżenie ulegać jego wpływowi, a dopiero później zacząć bezpośrednio do twórczości tej się odwoływać. Przeciwko takiej tezie świadczą jednak następujące ustalenia.

Podstawową kwestią jest ustalenie, kiedy Tischner, po raz pierwszy, nie tyle zetknął się Teodramatyka Balthasara, ile kiedy uzyskał do niej stały dostęp. Podanie konkretnej daty nie wydaje się możliwe, jednakże istnieją poważne przesłanki, które pomogą nam dokonać pewnego oszacowania.

Zauważmy przede wszystkim, że w jednym ze swych artykułów z roku 1997 zatytułowanym Podglądanie Pana Boga Tischner odnosi się do książki Bielera Freiheit als Gabe $e^{30}$. Mniej więcej w tym samym czasie ukazuje się Der dreieine Gott Greshakego. Obie te pozycje bardzo szybko przyciągają uwagę Tischnera, który w omawianym już wyżej ostatnim rozdziale Sporu o istnienie człowieka zalicza Balthasara do „najczęściej cytowanych przez Greshake’a [sic!] i Bielera autorów”31. Wygląda więc na to, że miał okazję zaznajamiać się z myślą Balthasara, przynajmniej poprzez prace Greshakego i Bielera, już około roku 1997. Tyle możemy wywnioskować z samych prac Tischnera.

Jest to jednak z pewnością dość znaczne niedoszacowanie. Tischner o Balthasarze musiał słyszeć już wcześniej, choć niekoniecznie miał stały dostęp do jego dzieł. Trzeba pamiętać o skutecznej zaporze, jaką przed transformacją ustrojową stanowiła w Polsce „żelazna kurtyna”. Po zmianach ustrojowych, na początku lat dziewięćdziesiątych, rozpoczęto starania, aby wzbogacić bibliotekę ówczesnego krakowskiego PAT-u o - dotąd niemal nieosiągalne - dzieła współczesnych teologów zachodnich.

Z rozmów, jakie autor niniejszego artykułu odbył z pracownikami naukowymi krakowskiej uczelni, którzy mieli okazję współpracować w tamtych czasach z Tischnerem, wynika, że zyskał on stały dostęp do Teodramatyki Balthasara około roku $1995^{32}$, i to ten rok należy przyjąć za najbardziej wiarygodną datę

${ }^{30}$ J. Tischner, Podglądanie Pana Boga, „Znak” 511 (1997), s. 23.

${ }^{31}$ J. Tischner, Spór o istnienie człowieka, dz. cyt., s. 395.

${ }^{32}$ W szczególności bardzo cenna była rozmowa $\mathrm{z}$ ks. prof. J. D. Szczurkiem, obecnym dyrektorem Instytutu Teologii Dogmatycznej UPJPII, który podzielił się ze mną informacją, że osobiście sprowadzał dzieła Balthasara do biblioteki naszej krakowskiej uczelni właśnie w połowie lat dziewięćdziesiątych. Informację tę zweryfikowałem w Bibliotece (dziś już) UPJPII: Teodramatyka Balthasara została zarejestrowana jako nabytek biblioteczny Biblioteki PAT w Krakowie pod datą: 19.10.1995 (jest to najwcześniejsza data zarejestrowania czwartego tomu Teodramatyki, tj. egzemplarza o numerze 1060017051; drugi egzemplarz, o numerze 1060013745, zarejestrowany został pod datą 13.04.1998). 
uzyskania przez niego pełnego i stałego dostępu do wspomnianego dzieła szwajcarskiego teologa.

Trzeba tu jednak wziąć jeszcze pod uwagę pewne dodatkowe okoliczności. Mianowicie sama Teodramatyka to cztery opasłe tomy napisane dość specyficznym Balthasarowskim językiem niemieckim, a cała Trylogia to już tych tomów kilkanaście (o czym wspominał z resztą sam Tischner). Biorąc pod uwagę nawet bardzo dobrą znajomość języka niemieckiego u Tischnera, ale także jego rozliczne obowiązki i coraz bardziej podupadające zdrowie, trzeba być świadomym, że przyswojenie sobie tak obszernego dzieła nie mogło być kwestią miesiąca czy dwóch, i to nawet w przypadku tak genialnego myśliciela.

Koleją kwestią jest wpływ tej lektury na myśl Tischnerowską - nie mógł być on na pewno natychmiastowy. Nie dziwi więc fakt, że pierwsze bezpośrednie wzmianki o Balthasarze pojawiają się u Tischnera dopiero w latach 1997-1998.

Nie możemy się tu ograniczyć jedynie do rozważań natury chronologicznej. Nie mniej ważna jest analiza lingwistyczna. Jak już mieliśmy okazję przekonać się w poprzedniej sekcji, tam gdzie Tischner wyraźnie odwoływał się do Balthasara, tam też niemal natychmiast można było wychwycić wpływ tego autora na Tischnerowską terminologię. Warto więc zapytać, jak to wyglądało przed rokiem 1997.

Do roku 1997 w myśli dramatycznej Tischnera dominuje zdecydowanie terminologia Lévinasa, czyli terminy, takie jak „,agatologia”, „twarz”, „inny”, „pragnienie”, „więź”, „świadectwo”, czy też słownictwo zaczerpnięte ze wcześniejszych jeszcze zainteresowań fenomenologią i filozofią człowieka („doświadczenie”, „obserwacja”, „otwarcie intencjonalne”, „otwarcie dialogiczne”, „horyzont”, „aksjologia”, „fatum”, „wybór”, „ofiara”). Nie są to słowa zaczerpnięte od Balthasara. Słowa kluczowe będące wręcz etykietkami myśli teodramatycznej szwajcarskiego teologa, takie jak: „teodramatyka”, „agogika”, „rola-misja”, „Wolność skończona”, „wolność nieskończona”, u Tischnnera przed rokiem 1997 po prostu nie występują, za wyjątkiem oczywistych koincydencji czysto werbalnych, niezwiązanych ani z kontekstem, ani ze specyficznym znaczeniem, jakie nadaje im Balthasar.

Warto w tym kontekście nadmienić, że Balthasar i Tischner podają niezależnie od siebie dwie odmienne, nowatorskie, dialogiczno-dramatyczne definicje pojęcia osoby ${ }^{33}$.

${ }^{33} \mathrm{~W}$ niniejszym artykule nie ma miejsca na rozwijanie tego wątku. Zainteresowanego czytelnika odsyłamy do L. Wołowski, L’approccio agatologico-cristologico al concetto di persona nella riflessione 
Na zakończenie tej krótkiej analizy terminologicznej trzeba jeszcze wspomnieć o bardzo wymownym, wręcz symbolicznym fakcie, iż przed rokiem 1998 Tischner nigdy nie używa terminu „teodramatyka”, zamiast tego, co ciekawe, ukuł własny niezależny „odpowiednik”34, w postaci wyrażenia: „dramat człowieka z Bogiem"35.

\section{Wnioski końcowe}

Wszystko to, co ustaliliśmy do tej pory, pozwala na sformułowanie ostatecznych wniosków. Pomimo sporadycznej zależności myśl dramatycznej Tischnera w okresie ostatnich dwóch lat jego twórczości, można mówić o praktycznie całkowitej niezależności myśli obu autorów. Słuszna wydaje się więc teza, postawiona na początku niniejszego artykułu, że udziałem obu tych autorów stało się to samo zjawisko „nieprzyczynowej równoczesności”, w jakim ponad pół wieku wcześniej przyszło uczestniczyć Ebnerowi, Buberowi, Marcelowi i Rosenzweigowi, w kontekście powstawania tzw. filozofii dialogu.

Powróćmy więc jeszcze na moment do tego cytatu, od którego rozpoczęliśmy nasze rozważania, a ściślej do następującego jego fragmentu: „Martin Buber, który do trzeciej i ostatniej części swojego Ja $i$ ty, dodaje wpływ Ebnera, ale do swoich centralnych założeń doszedł na podstawie o wiele wcześniejszych przemyśleń własnych" ${ }^{36}$. Sytuacja ta uderzająco przypomina okoliczności, w których Tischner tworzył swój Spór o istnienie człowieka, oparty niemal w całości na jego własnych przemyśleniach (ściślej: niezależnych od Balthasara) i uzupełniony jedynie w ostatnim rozdziale o odnośniki do prac szwajcarskiego teologa.

Można powiedzieć, że historia zatoczyła swego rodzaju koło. To, co działo się w filozofii i teologii dialogu w latach dwudziestych $\mathrm{xx}$ wieku, w wykonaniu wspomnianych wyżej myślicieli, to powtórzyło się w latach osiemdziesiątychdziewięćdziesiątych w filozofii i teologii dramatu w wykonaniu Balthasara i Tischnera.

teatrologica-teologica di Hans Urs von Balthasar e di Józef Tischner, „Polonia Sacra” 23 (2019) nr 1 (55), s. 31-51.

34 Słowo „odpowiednik” umieszczamy w cudzysłowie, by podkreślić, że chodzi tu o wyrażenie wprowadzone przez Tischnera niezależnie od Balthasara, a nie jako alternatywa wobec terminologii szwajcarskiego teologa.

35 J. Tischner, Filozofia dramatu, dz. cyt., s. 21.

36 H. U. von Balthasar, Teodramatyka, t. 1, dz. cyt., s. 595. 
Trzeba jednak dodać, z nutką niedosytu, że mimo, iż tamci czterej „ojcowie dialogizmu” przeszli niemal równorzędnie do historii swoich dziedzin, to w przypadku Tischnera i Balthasara wciąż mamy do czynienia z niezrozumiałą wręcz dysproporcją. Balthasar znany jest już niemal wszędzie i przez wszystkich jako czołowy przedstawiciel nurtu myśli dramatycznej, zwłaszcza $\mathrm{w}$ teologii, ale po części również i w filozofii. Tischner, który główny nacisk kładł na filozofię dramatu, ale nie stronił również od wątków teologicznych, w szerszych kręgach światowych nie zdołał niestety przebić się jeszcze do świadomości jako jeden z niezależnych prekursorów tego podejścia.

Warto więc zdawać sobie w pełni sprawę z ogromnego i oryginalnego wkładu tego wybitnego krakowskiego myśliciela w tej dziedzinie.

\section{Abstrakt}

W niniejszym artykule podejmujemy problem niezależności myśli dramatycznej Józefa Tischnera oraz refleksji teodramatycznej Hansa Ursa von Balthasara. Wykazujemy, iż obaj autorzy, pomimo zbliżonego podejścia ogólnego i pewnych podobieństw w niektórych aspektach szczegółowych, rozwijają swą myśl (teo)dramatyczną niezależnie od siebie. W przypadku Balthasara można mówić o całkowitej niezależności od Tischnera. W przypadku Tischnera analizujemy przykłady formalnej zależności jego tekstów od Balthasara (cytowanie grzecznościowe, zapożyczenia terminologiczne) i wykazujemy, iż zależność ta ma charakter czysto marginalny i dotyczy jedynie ostatnich dwóch lat jego życia. We wniosku formułujemy więc tezę o „nieprzyczynowej równoczesności” dotyczącą wkładu obu autorów w rozwój tzw. nurtu dramatycznego, nawiązując w ten sposób do analogicznego zjawiska, o którym pisał sam Balthasar w kontekście prekursorów nurtu dialogicznego.

\section{SŁOWA KLUCZOWE}

filozofia dramatu Tischnera, teodramatyka Balthasara, niezależność myśli

\section{ABstract}

\section{The problem of independence of Józef Tischner's dramatic} reflection from Hans Urs von Balthasar's theodramatic thought

In this article we address the problem of the independence of the dramatic thought of J. Tischner and theodramatic reflection of H. U. von. Balthasar. We show that both authors, despite some resemblance in general approach and certain similarities in some specific aspects, develop their (theo)dramatic thought independently from each other. 
In case of Balthasar, one can talk about total independence from Tischner. In case of Tischner, we analyze the examples of formal dependence of his texts on Balthasar (courtesy citing, terminological borrowings) and we show that this dependence has a purely marginal character and concerns only the last two years of his life. As a corollary we formulate a thesis about „non-causal simultaneity” regarding the contribution of both authors to the development of the so-called dramatic current, referring this way to the analogical phenomenon that Balthasar himself discussed in the context of the precursors of the dialogical current.

\section{KEYWORDS}

Tischner's philosophy of drama, Balthasar's theodrama, independence of thought

\section{BIBLIOGRAFIA}

Balthasar H. U. von, Die Entwicklung der musikalischen Idee. Versuch einer Synthese der Musik, Fritz Bartels Verlag, 1998 (Rozwój idei muzycznej. Próba syntezy muzyki, w: Hans Urs von Balthasar, Pisma wybrane, t. 2: Pisma z zakresu sztuki i religii, tłum. M. Urban, D. Jankowska, Kraków 2007, s. 25-53).

Balthasar H. U. von, Geschichte des eschatologischen Problems in der modernen deutschen Literatur, Einsiedeln 1998.

Balthasar H. U. von, Herrlichkeit. Eine theologische Ästhetik, Bd. 1-3, Einsiedeln 19611969 (Chwała. Estetyka teologiczna, t. 1-3, tłum. E Marszał, J. Zakrzewski, Kraków 2007-2013).

Balthasar H. U. von, Theodramatik, Bd. 1-4, Einsiedeln 1973-1983 (Teodramatyka, t. 1-2, tłum. W. Szymona, Kraków 2005-2006).

Balthasar H. U. von, Theologik, Bd. 1-3, Einsiedeln 1985-1987 (Teologika, t. 1-3, tłum. J. Zychowicz, Kraków 2004-2005).

Bobko A., Myślenie wobec zła, Kraków-Rzeszów 2007.

Capol C., Müller C., Hans Urs von Balthasar. Bibliographie 1925-2005. Neu bearbeitet und ergänzt von Cornelia Capol und Claudia Müller, Einsiedeln-Freiburg 2005.

Guerriero E., Hans Urs von Balthasar. Monografia, Kraków 2004.

Jagiełło J., Zuziak, W., Bądź wolność twoja, Kraków 2005.

Piech S. L., Bibliografia prac drukowanych księdza Józefa Tischnera, „Analecta Cracoviensia" 37 (2005), s. 73-170.

Przekonać Pana Boga. Z ks. Józefem Tischnerem rozmawiaja Dorota Zańko i Jarosław Gowin, Kraków 2010.

Tischner J., „Épistémologie”, Fernand Van Steenberghen, Louvain 1947, [recenzja], „Collectanea Theologica” 26/4 (1955), s. 801-809. 
Tischner J., Dziennik 1944-1949. Niewielkie pomieszanie klepek, Kraków 2014.

Tischner J., Fenomenologia świadomości egotycznej, w: J. Tischner, Studia z filozofi świadomości, Kraków 2006, s. 131-417.

Tischner J., Filozofia dramatu, Kraków 2012.

Tischner J., Ja transcendentalne w filozofii Edmunda Husserla, w: J. Tischner, Studia z filozofii świadomości, Kraków 2006, s. 9-127.

Tischner J., Podgladanie Pana Boga, „Znak” 511 (1997), s. 8-24.

Tischner J., Przestrzeń obcowania z drugim, „Analecta Cracoviensia” 9 (1977), s. 67-86.

Tischner J., Spór o istnienie człowieka, Kraków 2011.

Tischner J., Życie wewnętrzne Boga, w: J. Tischner, Ksiądz na manowcach, Kraków 2007, s. 88-101.

Wołowski L., Laapproccio agatologico-cristologico al concetto di persona nella riflessione teatrologica-teologica di Hans Urs von Balthasar e di Józef Tischner, „Polonia Sacra” 23 (2019) $\mathrm{nr} 1$ (55), s. 31-51. 